821.163.41.08-32 Кочић П. https://doi.org/10.18485/sj.2018.23.1.19

САњА Ђ. МАЦУРА*

Универзитет у Бањој Луци

Филолошки факултет
Оригинални научни рад

Примљен: 04. 01.2018.

Прихваћен: 29. 01. 2018.

\title{
НАРАТИВНИ ПОСТУПЦИ У КОЧИЋЕВОМ „ЗУЛУМУ СИМЕУНА ЂАКА”
}

\begin{abstract}
У раду се, анализом наративних поступака, прије свега одабира врсте наратора, типова и особина фокализованог приповиједања и употребе виртуелног наратива, на примјеру приповјетке „Зулум Симеуна Ђака” Петра Кочића, жели указати на то да је код овога писца фокализација у директној спрези с наративном инстанцом, те да је избор одређене врсте нарације и типа фокализације примарно у функцији обликовања ликова и пројектовања догађаја, неријетко кроз употребу виртуелног наратива и дескриптивне нарације.
\end{abstract}

Кључне ријечи: нарација, фокализација, виртуелни наратив, дескриптивна нарација, П. Кочић

1. У свом сада већ вишедеценијском бављењу проучавањем наративних текстова, наратологија се на путу од класичне до посткласичне фазе посебно интересовала за начине презентовања наративне инстанце и перспективе из које су догађаји приказани, те за временске аспекте приче. Из тог интересовања произишао је комплексан терминосистем којим се идентификују, описују и у њиховој међусобној испреплетености анализирају елементи наративних поступака, првенствено позиција наратора, фокализација, темпоралност, спацијалност и поступци у обликовању ликова. Сваки од њих дио је каузалног наративног ланца као структуре састављене од наведених елемената и одређе-

"sanja.macura@flf.unibl.org 
не њиховим међусобним релацијама. Те релације могу да буду међусобно одређујуће (као нпр. позиција наратора која је доминантна у односу на тип фокализације чију природу одређује или пак повезаност темпоралних и спацијалних одредница у хронотоп), али и такве да их се ишчитава implicite.

Узимајући у обзир наведено, у овом раду анализирамо функцију фокализованог приповиједања, његову спрегу с наративном ситуацијом и употребом виртуелног наратива, те функцију наративизације описа на примјеру приповијетке „Зулум Симеуна Ђака” Петра Кочића. Наведени конституенти наративног каузалног ланца дистинктивни су фактор Кочићеве прозе, који се с почетка 20. вијека јавља у новој форми у односу према дотадашњем српској наративној прози. (в. Милосављевић Милић 2012: 817--818) Није тешко уочити да је, бар на први поглед, већина Кочићевих наративних текстова исприповиједана у трећем лицу, тј. из позиције екстерног наратора, што доприноси аутентизацији примарног наратива и обезличености перспективе наратора, те избјегавању подручја недоречености зарад претпостављене нараторске објективности. Па ипак, и поред тога, долази до помјерања управо те очекиване нараторске објективности ка субјективизацији репрезентовања ликова, тј. до пораста нивоа исказивања оних индивидуалних особина ликова које их издвајају из хронотопа унутар којег су ситуирани. У литератури је већ примијећено да већина Кочићевих ликова ${ }^{1}$ искаче „из онога што се у њиховом колективу сматра нормалним и уобичајеним", да Кочића заправо и не занимају типичне личности у типичним ситуацијама" (Лешић 1988: 96). То је изразито видљиво у Кочићевим наративним текстовима у којима наратор приповиједа у првом лицу. Било да је у питању лик актант или само свједок, углавном се не перципира његово активно учешће у фабули, иако се стиче утисак да је стално присутан у времену и простору о којем и из којег приповиједа.

1.1. Без намјере да понудимо преглед теоријских разматрања опсега и досега појма фокализације ${ }^{2}$, а у мору његових значења, разумијевања и тумачења ${ }^{3}$, за потребе овога рада одлучили смо се за једно од рјешења понуђених у доступној литератури, а које је засновано на ставовима М. Бал $(2000)^{4}$, која

${ }^{1}$ Већ смо писали о ликовима у Кочићевом циклусу приповиједака о Симеуну Ђаку (в. Мацура 2013).

${ }^{2}$ Жерар Женет је 1972. године, у складу са Пуилоновом „диобом на гледање одострага, гледање са и гледање извана, преузимајући апстрактнији и шири израз К. Брукса и Р. П. Ворена focus of narration, „лишен искључиво визуалних конотација” (Biti 1997: 101), предложио типологизацију фокализације на нулту, унутрашњу и вањску, при чему појам фокализација није прецизно дефинисан у ра ду у којем је представљен.

${ }^{3}$ Указујемо, између осталих, и на радове: Римон-Кенан $(1988,1989,2007)$, Четмена (1995); Фонтанела (Jacques Fontanille); Гремаса; Ф. Бастидеа (Frencois Bastide); Јовановић 2014, Вуловић 2015, Мацуре 2012.

${ }^{4}$ Под фокализацијом сматрамо „однос између презентованих елемената и визије кроз коју су они презентовани”, тј. „однос између визије и онога што се види, уоченог” (Бал 2000: 119). 
je, критикујући Женетово ${ }^{5}$ сагледавање феномена фокализације и сматрајући да је при разлучивању њених типова користио два различита критеријума ${ }^{6}$ (јер је вањску фокализацију одредио предметом, а не субјектом перцепције), кроз оспоравање постојања нулте фокализације и изношење става да је наратор, чак и када је екстерни, увијек у исто вријеме и фокализатор, М. Бал 7 је предложила двочлану типологију фокализације по којој би екстерна (вањска) фокализација била она која је одређена интегралним субјектом наратора, а интерна (унутрашња) фокализација она у којој је субјекат подвојен, тј. наратор је екстерни, а фокализатор интерни. При томе користимо појмове фокализација (интерна и екстерна), фокализатор, фокализовано (објекат фокализације) и опсег фокализације, при чему се кроз истраживање комбинација фокализатора и фокализованих добија јасна слика о њеном субјекту и објекту. Имајући на уму да „теорија фокализације обухвата различите начине регулисања/уређивања, одабира и каналисања наративне информације", те да је у питању особено виђење догађаја са неке тачке гледишта, без обзира на то колико ово становиште може бити субјективно или непоуздано" (Вуловић

Фокализатор је „тачка са које се елементи посматрају. Та тачка се може налазити при лику, дакле при елементу фабуле, или изван ње.” (Бал 2000: 124) Интерна фокализација је она која „се налази при једном лику”, а екстерни фокализатор је онај који „функционише као фокализатор изван фабуле” (Бал 2000: 124-125).

${ }^{5}$ Уводећи у теорију књижевности сада већ класични појам фокализације (Focalization према: Routledge Encyclopedia of Narrative Theory: 173-177; Prince 2003: 31-32; Biti 1997: 101-102; Herman \& Vervaeck 2005: 70-80, 155-157; Rimon-Kenan 2002: 92-109; Porter Abot 2009: 120, 125-127, 200-203; Bal 2000: 119-139; Genette 1972), Ж. Женет је, полемишући с тада већ постојећим класификацијама које су за своје полазиште узимале тачку гледишта (point of view), начинио искорак раздвојивши питање „ко говори” од питања „ко види” и понудио трипартитну схему у којој су се нашле нулта фоклаизација (ефокализовано приповиједање, тј. нефокализовани текстови са тзв. свезнајућим или omniscient наратором који угл. приповиједа у 3. лицу), унутрашња или интерна фокализација (у којој су догађаји предочени с позиције неког од ликова) и вањска (спољашња, екстерна) фокализација (при којој наратор износи само догађаје, без упуштања у разматрање унутрашњег свијета ликова). Уз наведене типове фокализације, Ж. Женет уводи и појмове алтерација или преиначење, који означава одступање од доминантног типа фокализације, а два су типа алтерација - паралипса (давање мањег броја информација) и паралепса (давање већег броја информација), те полимодалитет који означава комбиновање различитих наративних система у истом тексту. Женет, није остао на својој првобитној позицији, него је 1983. године одустао од њеног иницијалног одређења и именовања понудивши рјешење у виду појма фокус, базираног на питању „Гдје се налази фокус опажања?”.

${ }^{6} \mathrm{Tj}$. нулту и унутрашњу фокализацију разликовао је по позицији наратора који је у нултој фокализацији свеприсутан (omnipresent) и свезнајући (omniscient), а у унутрашњој фокализацији види само оно и онолико шта и колико види лик, док се унутрашња и вањска фокализација разликују не по положају наратора, него по положају лика који је у унутрашњој фокализацији онај који види, а у спољашњој онај који је вићен.

${ }^{7}$ Осим наведеног, М. Бал (в. 2000) је увела и појмове фокализатор (focalizer) - субјекат фокализације (в. Prince 2003: 32) и фокализовано (focalized) - објекат фокализације (в. Prince 2003: 32), те тзв. нивое фокализације (i.e. фокализацију у фокализацији при којој лик-фокализатор из првог нивоа фокализације постаје фокализовани, односно објекат фокализације у другом нивоу еtc). 
2015: 533), фокализацију посматрамо напоредо с наратором ${ }^{8}$, јер у његовом односу према актерима о којима се с одређене позиције приповиједа и које се са одређене позиције посматра, те кроз анализу релација између нарације, фокализације и дескрипције ${ }^{9}$ као елемената система наративног текста који су субмисивни према резултатима активности различитих наративних инстанци (посебно наратора ликова) као диминанти, анализирамо и тумачимо њихове односе и хијерархијску међузависност ${ }^{10}$.

1.2. Избор једног од типова наратора (екстерни и интерни с подтиповима лика актанта и лика свједока) нужно условљава и изабрани тип фокализације. Тако нпр. у нарацији у првом лицу, када је наратор позициониран кроз комбиновање његовог дијахроног (млађег) ја и синхроног ја (онога из времена из којег се приповиједа), „дисонантни приповедач [тј. наратор, оп. С.М.] посматра своје млађе ја ретроспективно, често се дистанцирајући од пређашњег незнања и заблуда, а износећи доста потоњих сазнања. Консонантни приповедач [тј. наратор, оп. С.М.], насупрот томе, не истиче свој накнадни увид и идентификује се са својом млађом инкарнацијом тако што одбацује све сазнајне повластице." (Edmiston 1995: 96) При анализи описа и њихове наративизације морали бисмо, како наводи С. Четман (1990: 37) ${ }^{11}$, избјегавати неспретне формулације попут оне да наратор описује такав и такав догађај, у случајевима када је његова функција да дескрипција буде дио описане сцене (поставке) а не повезница у догађајном ланцу, јер се догађаји који су релевантни за причу (сиже) само приповиједају [,narrate”, оп. С.М.], а никако не описују [,„escribe”, оп. С.М.]. Улога било којег догађаја (активности), од чега год да се он састоји, није наративна уколико он није у хронолошком каузалном

\footnotetext{
${ }^{8}$ У раду користимо термин „наратор” (енгл. narrator) за који је у једном броју превода књижевнотеоријских текстова на српски језик употријебљена лексема „припов(ј)едач”, јер је лексемом припов(ј)едач у српском језику већ означен свако онај ко приповиједа (нпр. писац приповиједака или усмени приповједач), а лексема наратор означава само одређену наративну инстанцу у наративном тексту (i.e. даје одговор на Женетово питање „ко говори?”).

${ }^{9}$ Разматрајући питања описне нарације, С. Милосављевић Милић (2016) указује на то да „У теоријској литератури иначе не постоји сагласност у погледу дефинисања описа и њихових подврста и функција.” (242)

${ }^{10}$ Уз наведено, свакако треба указати и на настојања Ш. Римон-Кенан (2007) да трипартитну Женетову типологију фокализације допуни неким ставовима Мике Бал (2000). У складу с тим, а полазећи од ставова и класификације М. Бал, Ш. Римон-Кенан фокализатора дијели на унутрашњег и спољашњег, те истовремено апострофира нужносте суплементовања женетовски схваћене фокализације њеним различитим аспектима: опажајним аспектом (нпр. визуелни, аудитивни, олфакторни, тактилни), психолошким аспектом (когнитивни и емоционални), те идеолошким аспектом.

${ }^{11}$ "....we should avoid such sloppy expressions as 'the narrator describes such and such a narrative event.' Objects and characters may be described, but actions are 'described' only if they function as part of teh described settings rather than as links in the event chain. Story-relevant events are only 'narrated', nor described. The function of an action, whatever its inner constitution, is not narrative if it is not in the chrono-logic-not keyed, that is, to the ongoing march of story events."
} 
слиједу, тј. уколико није дио слиједа догађаја у сижеу. На подразумијевану супротстављеност дескриптивног и наративног указује и Р. Ронен $(1997: 274)^{12}$ која, „међутим сматра да је дескрипција теоријски конструкт проистекао из потребе да се означи супротно нарацији... те да у том смислу од ове опозиције треба одустати". (Бубања 2015: 430)

1.3. Уз позицију наратора и фокализацију, те наративизовану дескрипцију, у каузални наративни ланац укључујемо и виртуелни наратив ${ }^{13}$ у улози секундарне фабуле, као важан фактор у структури наративног текста. Поимање виртуелног наратива проистиче из изразитог интересовања наратологије за темпоралну компоненту наративног текста, почев од Р. Барта ${ }^{14}$, Ж. Женета ${ }^{15}$, М. Бал ${ }^{16}$, П. Рикера ${ }^{17}$ (1993), те Х.П. Абота ${ }^{18}$, па све до других савремених, посебно когнитивних наратолога чији концепт виртуелног наратива „значајно редефинише темпоралне фигуре класичне наратологије” (Милосављевић Милић 2013: 13), дословно се погравајући њима. Виртуелни наратив ${ }^{19}$ је битан сегмент наративне структуре (в. Ryan 1986), као „неаутентизована могућност која покрива субјективни домен лика" (Долежал 2008: 160) у којој се налази оно што се могло догодити, али се није догодило. Он је углавном садржан у неком неоствареном наративу из прошлости лика, али се јавља и као могућа али неостварива садашњост или будућност, те као негација. Као такав, он

12 "... this opposition is accepted as almost axiomatic".

${ }^{13}$ У овом случају, секундарна фабула је обиљежена кроз неаутентизованост (в. Долежел 2008: 160), неприповједиво (nonnarratibile/unnarratibile), неприповиједано (unnarrated/nonnarrated) и контраприповиједано или диснаративно (disnarrated). (в. Принс 1988, 2003; Рутлиџ 2010 и Милосављевић Милић 2016а).

${ }^{14}$ Барт наглашава да је његов задатак или бар „жеља - постићи да се оствари структурална дескрипција хронолошке илузије”, а да је „на наративној логици ... да води рачуна о наративном времену" (1971: 68)

${ }^{15}$ Женет успоставља читав терминосистем (анахронизам, аналепса, пролепса, домашај, амплитуда и др.) описујући и анализирајући организацију времена у наративном тексту.

${ }^{16}$ Балова вријеме посматра као елеменат фабуле, тј. материјал за њену изградњу (2000: 14), а догађаје дефинише као процесе, а процесе као промјене које претпостављају сукцесију у времену или хронологију. (2000: 172)

${ }^{17}$ Рикер (1993) је указао на интерпретативну потенцијалност тензије базиране на односу између интерпретације заплета као укидања времена и времена као иманентне димензије заплета наводећи да „Ако је тачно да је главна тежња модерне теорије приче - како у историографији, тако и у наратологији, да 'дехронологизује' причу, борба против линеарног представљања времена нема нужно за исход само 'логичност' приче, већ и продубљивање њене темпоралности” (44), при чему је људском искуству приписао једну почетну „наративност” (98) истичући да ће се „временска форма, својствена искуству и приповедна структура непрестано тумачити једна помоћу друге". (100)

${ }^{18}$ Х.П. Абот наратив не посматра као нешто што је иманентно само књижевном дјелу, него и човјековом битисању уопште, сматрајући да је „наратив основни начин на који људска врста организује своје поимање времена”. (2009: 27)

${ }^{19}$ Снежана Милосављевић Милић указује на то да је „важно направити разлику између виртуелног наратива и виртуелности наратива као његове иманентне особине”. (2012: 818) 
има важну улогу као компонента обликовања ликова. Поимање виртуелног наратива $^{20}$ засновано је, између осталог, и на добро познатој аристотеловској категорији пробабилитета (могућносног, вјероватног) која се у оквирима когнитивне наратологије ослања на опозитни пар актуелно - могуће, односно у Епштејновој (2002) интерпретацији на пар вјероватно - потенцијало, при чему је могућносно интензивирано одмаком од потенцијалног ка вјероватном.

Три су основна облика јављања виртуелног наратива: као негације, као могуће неостварене приче из прошлости и као могуће, али извјесно неоствариве будућности, „при чему, као негација, овакав наратив наглашава антитетичку релацију наспрам једног имплицитног, подразумеваног, познатог или уобичајеног стања ствари или тока збивања. Њиме се примарни ток догађаја показује као измештени, децентрирани, или понекад погрешни, налик на потенцијалну аномалију... Тиме се идентитет лика изграђује, не на оном што јесте, већ на ономе што није, као на својеврсном пољу празнине... Будући да је реч о нереализованој могућности, виртуелни наратив као своје иманентно својство носи антитетичку релацију наспрам актуализоване приче.” (Милосављевић Милић 2012: 820) Виртуелни наратив може да буде усмјерен према прошлим догађајима и тада представља лажну, погрешну верзију збивања (аналептички виртуелни наратив), али може бити усмјерен и ка будућим догађајима, као њихова могућа верзија (пролептички виртуелни наратив) ${ }^{21}$. Алтернација усмјерена ка будућим догађајима може да буде боља (пожељнија) или гора (непожељнија) варијанта наративног синхроног тренутка у којем почиње пролепса. Док је аналептички виртуелни наратив затворен за наративну садашњост и не може бити модификован јер је означен дијахроношћу, пролептички виртуелни наратив је отворен ка будућности и самим тим подложан некој врсти „преиспитивања” до које долази кроз реализацију актуелизованог исхода, који може а не мора да буде контрапункт виртуелном наративу. Управо оваква изукрштаност теморалних равни до које долази при покушају ситуирања виртуелног наратива унутар темпоралне осе наративног текста, изњедрила су закључак да је „виртуелна прича у основи атемпорална, њено време је нулто време”. (Милосављевћ Милић 2013: 16) Да се закључити

${ }^{20} Џ$. Принс уводи три гранична случаја: неисприповиједано (nonnarrated), неприповједиво (nonnarratable) и контраприповиједање (disnarrated). Прва два поступка указују (упућују) на садржај који остаје изван приче, а контраприповиједање на нивоу приче постоји као паралелни, алтернативни наратив, који остаје нереализован. „The elements in a narrative that explicitly consider and refer to what does not take place („X didn't happen”; Y could have happened but didn't”). These elements constitute an important means of emphasizing TELLABILITY.” (Prince 2003: 22)

${ }^{21}$ Милосављевић Милић (2013: 14) истиче да „уколико на морфолошком плану апстрахујемо виртуелни наратив и посматрамо га као 'уметнуту причу', што он по свом обиму често и јесте, унутар те приче можемо успостављати бинарну опозицију између фабуле и сижеа. Овакав вид темпоралног уланчавања водио би хипотетички до познатог феномена кинеских кутија, при чему би строга методолошка доследност затворила увиде у сложеност темпоралних нивоа". 
да виртуелни наратив почива на дистинктивној опозицији актуално - могуће и хипотетизму, тј. двјема категоријама могућег - потенцијалном и вјероватном, при чему је потенцијално виђено као унутрашње својство субјективног дјеловања, а вјероватно као чинилац објективних околности (Епштејн 2001), те је сам виртуелни наратив објашњен управо на наведеној бинарној опозицији актуалног и могућег. (Ryan 1986) Он означава нереализоване жеље, планове или намјере ликова, те погрешне ретроспективне интерпретације прошлих догађаја. „Логика виртуелног почива на логици замене и премештања... На плану лика у књижевном тексту то је појава двојника и „транссветовних идентитета”. Супротстављајући се реалном и актуелном, надмећући се са њима, ВН [виртуелни наратив, оп. С.М.] постиже значајан учинак у погледу децентрирања и дестабилизације реалности.” (Милосављевић Милић 2016: 40-41)

2. Кочићева приповијетка „Зулум Симеуна Ђака” почиње дескрипцијом пасивног типа који је супротан наративном:

Јесен се поодавно одомаћила. Све је срађено. Кукурузи се перушају, конопље набијају, а и котлови су почели пећи.

Игуман је извадио дозволу и јуче још пред зору наставио котао. Примакао је један ред преко дозволе, али игуман је, па неће на њег’ ни свијет ни суд. Тако он, кажу, ради сваке јесени.

Сједи се око котла, помало пије и прича, да котлар не задријема. Одмах до пинте сједи Симеун Ђак. $(127)^{22}$

Овај дескриптивни интерлудиј само је привидно, кроз употребу пасивних и обезличених реченица, лишен наративности. Оно што је основа наративности (најмање два каузално повезана догађаја) овдје је уткано у наративну дескрипцију која функционише као почетни позоришни призор у којем нешто тек треба да се деси након што сви актери и аксесоар буду распоређени на унапријед одређена мјеста. Јесен значи смирај природе, завршетак пољских радова и почетак печења ракије, што је увертира за цјелоноћно сједење око котла и приповиједање уз дегустирање нове ракије. У наведеном сегменту, али и у готово читавом остатку овог наративног текста прикрива се или чак лажно указује на тип наратора. Наиме, цјелокупан табло постављен је тако да је логична екстерна нараторска позиција. И, као таква, ова „варка” је досљедно испоштована, те се стиче утисак објективности екстерне нарације. На стварну, примарну нараторску позицију указује само дио кратког дијалога између котлара Мићана и Петрића (наратора свједока).

- Знаш ти, збиља, Петрићу, какав је зулум Симеун починио у Бронзаном Мајдану? - упита ме котлар Мићан и сагну се да сјарне ватру. (127) [подв. С.М.]

Само он (дијалог) указује на то да је наратор интерни. Његова права природа у остатку наративног текста „пребојена” је, маргинализована, чак

${ }^{22}$ Сви наводи из извора дати су према: Кочић 1972, па у загради иза наведеног цитата стоји само број странице. 
доведена у субмисивну позицију доминантношћу обједињавања индивидуалних нарација које наратеру предочава исти глас постављен готово у екстерну позицију. Да би тај глас био поуздан, да би му се вјеровало, мора да буде дио микрокозма сконцентртисаног око ракијског котла (дакле при лику), а да би могао да сагледа и пренесе општост морао би истовремено да буде и екстерни (дакле омнисциентни) поглед из зоне макрокозма означеног урбаним које почива на одсуству интеграције унутар заједнице. Иманентну интеграцију и комунални дух додатно апострофира спацијална ограниченост печења ракије која сужава догађајни простор и доводи до растезања времена, јер се у малом простору актери крећу спорије, а њихова нарација траје дуже. Осим тога, комунални дух руралног одређује природу односа између ликова. Они се сви добро познају, њихови животни наративи међусобно су испреплетени и општепознати у средини у коју су ситуирани. Стога је лик Петрића као некога ко је само повремено присутан у предметном хабитусу ликова неопходан и као дио микрокозма у којем све већ има своје стално мјесто, али и одраз макрокозма као носилац перспективе која није омеђена локалним хабитусом осталих ликова. Да би у таквој ситуацији наратор остао објективан, он не може као актант да партиципира у догађајима, нити у њима може да буде само пацијенс. Стога је избор позиције наратора-свједока који истовремено разумије и досљедно преноси догађаје плодоносан, али истовремено мора да буде редукован у коментарима и допуњен нарацијом других ликова као другостепеном. на тај начин, првостепена нарација припада Петрићу као наратору свједоку и он је интегрални дио оквирне фабуле, а другостепена нарација припада Симеуну Ђаку који је интегрални дио и оквирне (примарне) и уоквирене (секундарне) фабуле о којој као лик наратор приповиједа. Хармонизација ова два степена нарације и даје утисак да је наратор оквирне фабуле екстерни.

2.1. Око котла су окупљени различити ликови, између којих су наративно посебно маркирани Симеун као наратор о којем се приповиједа и котлар Мићан као иницијатор Симеунове нарације. Транзициона тачка између свакодневнице и свијета Симеунове нарације је тренутак у којем котао прокапава, а на који се репетитивно указује: - Још мало, па ће прокапати!; Само што није прокапало!; Дај свијећу, - прокапа котоิ!; Котао прокапа.; Сама прва кап! (127-128) Котлар Мићан иницира Симеунову нарацију, акцелерише је чашицама ракије, те њен почетак бива потпуно синхронизован са транзиционом тачком прокапавања котла: „Котао прокапа, Симеун отпоче.” [нарацију, оп. С.М.] С обзиром на природу нарације која је на првом нивоу условљена интерном позицијом наратора свједока, те екстерном фокализацијом одређеном интегралним субјектом наратора, наведена транзициона тачка истовремено је и трансформативна, јер почетак Симеунове нарације истовремено доводи до промјене типа наратора из свједока (Петрић) у наратора који је лик и актер (Симеун Ђак), и до трансформације дотадашње објективне у субјективну нарацију која улази у 
сферу виртуелног наратива. Петрићева нарација обиљежена је прекидношћу, клизи с једног на други објекат пажње, тј. са Симеуна који приповиједа о свом доживљају, на „некога из мрака” и „онога иза каце”:

- Е, људи моји, нит је так'ије' нишанџијаิ кад било, а какав је земан настоิ, тешко да и’ и буде, - дочека неко из мрака." (128); - Богме је тако, Симеуне! - уздахну неко у мраку. (128) - Што не наточиш чојеку чашу ракије, Мићане?! - набрекну један на котлара. - Видиш, стегло се чојеку грло, па не мере да приповиједа. (129); - Е, људи, да и то чујем док нијесам умро: шјен брез сунца! - чу се неко иза каце. (130); Симеун у одушевљењу одиста и отпјева, а неко дочека из мрака: - Не чуј вило, не преузми гласа! (130); - Де-де, Мићане! Нали чојеку чашу ракије.(131); - Боже мој! - чуди се један. - Коิ оно вријеме! Онда је могло свашта бити. (131); - Људи моји, нит је так'ије' јунака кад било, а какав је вакат настоิ, тешко да и’ и буде! - чуди се и крсти онај за кацом. (133),

који својим упадицама и коментарима или подстрекавају Симеуна на даље причање или пак преиспитују истинитост онога што он казује, те на котлара Мићана који прво иницира а онда и потпомаже Симеуново причање, што досипањем ракије, што репетицијом посљедњих ријечи изговорених пред прекид нарације:

- Ево га [Мићана, о.п. С.М.], нек ти приповиједи. (127); - Так’и ми се рађали! - узвикну весело Мићан и пружи му [Симеуну, о.п. С.М.] пуну чашу башице... - Де-де, даље причај. (128); - Ђе оно стадо’ ја [Симеун, о.п. С.М.]? - Нође: „А већ, вели, не гине ти оку-двије ракије попити, па...” - исправи га котлар (129); - Де-де, Симеуне, што си стао? Приповиједај, да видимо шта ће бити - вели Мићан и пружи му опет пуну чашу башице. (131).

Континуалност своје нарације прекида и Симеун сам, обраћајући се котлару Мићану и тражећи од њега још ракије:

- Наточи ти мени, Мићане, једну чашу - вели Симеун... (127); - Наточ'-де ми једну, Мићане! (129) - Ама, наточи ми, Мићане, једну, пост јој њезин! (129); - Ули-де једну, Мићане. (130); - Нали-де једну, Мићане! (131); - Мићане, наточи ми једну, пост јој њезин, да разбијем старе дерте! (133).

Прекиди у нарацији нису ретардативног типа, иако дјелимично успоравају окончање догађајног низа о којем се приповиједа. По својој природи ови прекиди имају улогу дескриптивне нарације и у функцији су обликовања лика Симеуна Ђака, јер указују на његове особине (склоност ка ракији, потреба за причањем и претјеривањем), тако на начин на који га виде други ликови, а и одраз су његове слике о себи самом, тј. аутоимаж (autoimage), како оне реалне, тако и виртуелне.

2.2. Симеунов виртуелни аутоимаж подлогу има у праситуацији епске пјесме. „Почетна ситуација... наговјештава оживљавање једног традиционалног епског свијета: јесен је, послови су се посвршавали, пао је мрак и људи су се окупили око ракијског казана, жељни приче о старим временима и старинском јунаштву... Али одмах затим постаје јасно: епска времена су давно прошла." (Лешић 1988: 91). У складу с традиционалним епским свијетом, Симеун себе 
назива „Симеун Пејић Рудар, ђак од манастира Гомјенице” (133), а приповједно вријеме ситуира у „прву неђељу иза укопације”. Употребљавајући у свом казивању епске формуле и за свједока позивајући покојника, оца Партенија („Ено му гроба, нек ми не да лагати.” 128), Симеун хиперболише све о чему приповиједа (попут Крајишника којих је између седамдесет двије и седамдесет три хиљаде, а броје их једног по једног он и Партеније). Симеунов виртуелни аутоимаж директно води ка обликовању виртуелног наратива, који је у овом случају такав да исказује не само оно што се није догодило, него и оно што није могло да се догоди а што је ситуационо обликовано тако да окупљени слушаоци исприповиједано аутентизују својим вјеровањем или „вјеровањем” у њега. Виртуелни наратив је углавном садржан у неком неоствареном наративу из прошлости лика, али може да се јави и као могућа али неостварива садашњост, те се према томе јавља као могућа неостварена прича из прошлости и као могућа, али извјесно неостварива садашњост. Као негација, виртуелни наратив наглашава антитетичку релацију наспрам имплицитног, сталног стања ствари, чиме се идентитет лика не изграђује на оном што он јесте, него на ономе што он није. У случају приповијетке „Зулум Симеуна Ђака”, виртуелни наратив одражава нереализовану причу из прошлости која се у имплицитној садашњости презентује као истинита, реализована и као такву је прихвата публика унутар које, истина, просијава глас „онога иза каце” као контрапункта општем ставу, мишљењу или пак носиоцу тог општег става и мишљења: „,- Е, људи, да и то чујем док нијесам умро: шјен без сунца! - чу се неко иза каце.” (130) Другостепени наратив који казује Симеун антитетичан је према првостепеном. Првостепени наратив који је исказан Петрићевом нарацијом у трећем лицу које указује на објективност у формализованом језичком изразу, у другостепеном, виртуелном наративу бива трансформисан у Симеуново приповиједање у субјективном, искуственом првом лицу, што резултира њиховом очигледном контрастивношћу. Вријеме приповиједања и приповједно вријеме сучељени су кроз дистинкцију између имплицитног и виртуелног наратива, једног из којег се приповиједа и другог о којем се приповиједа. неостварени наратив из прошлости, о којем окупљенима казује Симеун, означен је духом и идиомом српске народне епике, од ритуалног одијевања јунака пред бој (у овом случају Симеунов прерушавање у „швапску шкрљачину” и „,овинцирску... генералску кабаницу" (129) које је одавно већ покојни Партеније купио за зла времена (а она су ту, у времену из којег Симеун приповиједа уз казан ракије), опасавања сабље која „по земљи се вуче” (130), огледања сјене прије но што Сунце гране, узјахивања ата, подвикивања „грлом јуначкијем” да ,јече, људи, горе и гудуре" 131), а све зарад узвраћања зулума Крајишницима Мајданцима, при чему у тој освети проговара и мртва глава одрезана с Турчинових рамена. Оно што почиње као виртуелни аутоимаж који се претаче у виртуелни наратив прераста у изразито хиперболисану слику у којој се Симеун обрачунава са „’џом”, уз нараторски коментар дат у загради, који гласи „(И данас се од 
тог, међу нами буди речено, помало беслеишем и дуваним)” (133) а који другостепену нарацију укршта са првостепеном, уметнуту фабулу доводи у раван с оквирном, док виртуелни наратив издиже у раван имплицитног наратива, поништавајући у тој зони било какву границу која би међу њима требало да постоји и која би требало да указује на немогућност реализовања или на нереализованост виртуелног у поређењу с имплицитним наративом.

3. Анализа наративних поступака у Кочићевој приповијеци „Зулум Симеуна Ђака" показала је да је комбиновање два подтипа интерне нарације, оне у којој приповиједа лик свједок (Петрић) и оне у којој приповиједа лик актант (Симеун Ђак), те стварање привида постојања екстерне наративне инстанце која наизглед обједињава првостепени и другостепени наратив, условило својом природом и тип фокализације који је нужно интерни, а да су у перцепцији доминантни визуелни елементи. То је посебно видљиво у транзиционим и трансформативним наративним тачкама и у сужавању простора које доводи до растезања времена. Док је нарација у првостепеном наративу континуална, у другостепеном је изразито прекидна, али не и ретардативна, него у функцији наративне дескрипције. Та наративна дескрипција одређује спацијалне и темпоралне одреднице кроз низање активитета прирођених имплицитној ситуацији. Аутоимаж Симеуна Ђака резултира виртуелним наративом који у себи носи особине нереализованости, немогућности будућег реализовања и негације кроз дистинктирање догађајних садржаја приповједног времена и времена приповиједања. Кроз укрштање првостепене и другостепене нарације виртуелни наратив бива измјештен у раван имплицитног наратива што поништава границу која би међу њима требало да постоји.

\section{ЛИТЕРАТУРА}

Абот 2009: H.P. Abot, Uvod u teoriju proze, Službeni glasnik, Beograd, 2009.

Bal 2000: M. Bal, Naratologija, Narodna knjiga/Alfa. Beograd.

Барт 1971: R.Barthes, Književnost. Mitologija. Semiologija, Nolit, Beograd.

Бегић 2016: М. Бегић, O српским писиима $X X$ века (изабрао и приредио Р. Вучковић), Андрићград.

Бекер 1983: M. Beker, Priča i njezina obrada - prilozi suvremenoj naratologiji, Književna smotra, br. 1-2, 15-26.

Бити 1997: V. Biti, Pojmovnik suvremene književne terminologije. Matica hrvatska, Zagreb.

Богдановић 1972: М. Богдановић, Два лика Петра Кочића, у: Епоха реализма (приредио М. Протић), НОЛИТ, Београд, 414-417. 
Бубања 2015: Н. Бубања, $O$,, наративизачији дескрипије” на примеру песме „Нема развалина лунарног града” Грега Битија, Српски језик, ХХ, Београд, 423-439.

Бут 1976: V. But, Retorika proze, Nolit, Beograd.

Вуловић 2015: Ј. В. Вуловић, После Женета: фокализаиија у очима посткласичне наратологије. Зборник Матице српске за књижевност и језик, књ. 63, св. 2, 533-551.

Гремас 1979: А. J. Greimas, Les actants, les acteurs, et les figures, поглавље уврштено у: Revija 2/1979.

Дучић 1969: Ј. Дучић, Петар Кочић, Моји сапутници, Сабрана дјела, Сарајево.

Едмистон 1995: V. F. Edmiston, Fokalizacija i pripovedač u prvom licu: jedna revizija teorije. „Reč”, 8, 95-101.

Епштејн 2002: M. Epštejn, Likovi koji misle (odlomak iz knjige „Filozofija mogućeg”), Polja, god. 47, 422, okt-nov. 2002, 23-30.

Женет 1972: G. Genette, Figures III, Paris. (кориштена су поглавља ове књиге уврштена у: Suvremena teorija pripovijedanja, Zagreb, 1992, ur. V. Biti и поглавља уврштена у: Polja 304-5/1984)

Ženet 1995: Ž. Ženet, Perspektiva i fokalizacija. Reč, god. 2, br. 8, Beograd, 83-86.

Јовановић 2014: Ј. В. Јовановић, Од свезнања до незнања-проблем фокализаиије у роману „Један разорен ум” Лазара Комарчића. Свет у књижевности - књижевност у свету. Тематски зборник радова (ур. Б. Димитријевић), Филозофски факултет, Ниш, 158-169.

Кочић 1972: Јауции са Змијања, Српска књижевност у сто књига, књ. 46, Нови Сад - Београд.

Крушевац 1972: Т. Крушевац, Петар Кочић, Јауии са Змијања, Српска књижевност у сто књига, књ. 46, Нови Сад - Београд.

Лазаревић 1972: Б. Лазаревић, Петар Кочић у: Епоха реализма (приредио М. Протић), НОЛИТ, Београд, 405-413.

Лешић 1988: Z. Lešić, Pripovjedači-Ćorović, Kočić, Andrić, Samokovlija, Humo, Veselin Masleša, Sarajevo.

Максимовић 2005: Г. Максимовић, Свијет и прича Петра Кочића. Бања Лука-Београд.

Максимовић 2010: Г. Максимовић, Комедиографски Орфеј и други огледи, Београд.

Марчетић 2003: A. Marčetić, Figure pripovedanja, Narodna knjiga, Beograd. 
Мацура 2012: С. Мацура, Наративни лавиринт - Улазак, НУБРС, Бања Лука.

Мацура 2013: С. Мацура, Наратив и ликови у циклусу приповиједака о Симеуну Ђaкy, Значај српског језика и књижевности у очувању идентитета Републике Српске II - Књижевни класици републике Српске: Кочић и Ћопић, зборник радова, ур. М. Ковачевић, Филозофски факултет Пале, 277-296.

Милосављевић Милић 2012: С. Милосављевић Милић, Виртуелни наратив као знак модернизаиије српск епрозе на почетку 20 века, „Иво Андрић у српској и европској књижевности”, Научни састанак слависта у вукове дане, МСЦ, Београд, 817-827.

Милосављевић Милић 2013: С. Милосављевић Милић, Виртуелна прича као изазов наратолошком проучавању темпоралности, Наука и савремени универзитет 2 (ур. Г. Максимовић), Ниш, 11-19.

Милосављевић Милић 2013а: С. Милосављевић Милић, Виртуелни наратив-парадигма (не)могућих прича, Српски језик, књижевност, уметност, II, Немогуће: Завет човека и књижевности (ур. Драган Бошковић), Крагујевац.

Милосављевић Милић 2016: S. Milosavljević Milić, Virtuielni narativ, Sremski Karlovci - Novi Sad.

Рикер 1993: P. Riker, Vreme i priča, Sremski Karlovci: Novi Sad.

Prince 2003: G. Prince, A Dictionary of Narratology (Revised edition), University of Nebraska Press.

Rimon-Kenan 2007: S̆. Rimon-Kenan, Narativna proza, Beograd.

Routledge Encyclopedia of Narrative Theory (Edited by: David Herman, Manfred Jahn and Marie-Laure Ryan), London and New York, 2010.

Ронен 1997: R. Ronen, „Description, Narrative and Representation”, Narrative (Ohio State University Press), vol. 5, No. 3.

Секулић 1972: И. Секулић, Петар Кочић дело у: Јауции са Змијања, Српска књижевност у сто књига, књ. 46, Нови Сад - Београд, 37-55.

Тутњевић 2004: С. Тутњевић, Два врха српске приповијетке - Борисав Станковић и Петар Кочић у: Тачка ослонца, ЗУНС, Српско Сарајево.

Четмен 1990: S. Chatman, Coming to Terms. The Rethoric of Narrative in Fiction and Film, Cornell Universitz Press, Ithaca and London.

Четмен 1995: S. Četmen, Likovi i pripovedači, Reč, Beograd, god. II, br. 8, 87-94 (превео В. Петровић). 
Успенски 1979: B. Uspenski, Poetika kompozicije. Semiotika ikone, Nolit, Beograd.

Херман, Вервек 2005: L. Herman \& B. Vervaeck, Handbook of Narrative Analysis, University of Nebraska Press.

\title{
NARRATIVE STRATEGIES IN KOCIC'S "ZULUM OF SIMEUN DJAK"
}

\begin{abstract}
Summary
The paper explores some specificities of narrative strategies in Petar Kocic's novel "Zulum of Simeun Djak". Primarily, this paper explores application of selection of type of narrator, forms, characteristics and types of focalized narration and focalization and especially usage and construction of virtual narrative. In this novel, focalization is directly related with narrative levels. Selection of a certain type of narrator (internal narrator used as an active character or as a witness) influences selection of focalization which is primarily in function characterization of characters (who are mostly round characters) and projecting of events, not rarely in usage of virtual narrative which emerges from Simeun's virtual autoimage. Transitional and transformational narrative points are related to descriptive narration based on situation of traditional production of rakija (type of brandy) in the fall. They are initial capsule for narration of Simeun Djak which is related to idiom of Serbian epic lyrics. In that way, presumed objectivity of narration is substituted by subjectivity of narration about events that are in the zone of disnarreted content.
\end{abstract}

Key words: narration, focalization, virtual narrative, descriptive narration, Petar Kocic 